\title{
Pongamia Pinnata as Alternate Liquid Dielectrics in Distribution Transformer: A Critical Study on the Property of Viscosity
}

\author{
T. Mariprasath, V. Kirubakaran* \\ Rural Energy Centre, The Gandhigram Rural Institute, India
}

Copyright (C) 2015 Horizon Research Publishing All rights reserved.

\begin{abstract}
Distribution Transformers are one of the imperative equipment in power system. The insulation design has an important role because it continuously energizes in a day. Due to electro mechanical stresses the operating temperature of distribution transformer will be increased which maintains with in limit using liquid dielectrics. Traditional mineral oil is used as liquid dielectrics in Distribution Transformer. Due to lack of fossil fuels and lesser biodegradability characteristics of mineral oil, the alternating liquid dielectrics are important. In this research work viscosity of pongamia pinnata oil is measured using PLINT TE 62 Bench Viscometer as per ASTM D445 standard. Water content analysis of the oil sample has to be measured by weight balance method and Breakdown strength of oil sample was measured by Nutronics oil test set as per IEC 60156. From the experimental analysis, the viscosity of pongamia pinnata oil is low as compared to RBDPO, Soyabean oil, Coconut oil and Sunflower oil. The moisture content of pongamia pinnata oil is significantly reduced during aging period and the average breakdown strength of pongamia pinnata oil is higher than that of conventionally used mineral oil.
\end{abstract}

Keywords Distribution Transformer, Alternating Liquid Dielectrics, Pongamia Pinnata Oil (Karanja Oil), Viscosity, Water Content Analysis, Breakdown Strength

\section{Introduction}

The first oil cooled Transformer was introduced by Brown of Germany in the year 1890 [1]. In power system Transformers are play a significant role [2]. The main classification of Transformers are Distribution Transformers (50-2500 kVA) and Power Transformers (above $2500 \mathrm{kVA}$ ) [3]. The insulation is playing an important role in the life time estimation of transformer. The main causes of Transformers failure are insulation degradation [4,5]. There are two types of insulation medium used in Transformer solid and liquid insulation medium. The solid insulation is made up on cellulose materials and liquid insulation is from mineral oil. Several decades in the transformer mineral oil is used heat transfer and insulation medium, for the reason that of its physical and chemical properties is suitable for use as a liquid dielectrics also availability and low cost of mineral oil. But now a day's several researchers are focused on alternating liquid dielectrics.

There are two important factors alternating liquid dielectrics are quite most important. First availability of fossil fuels because mineral oil is extracted from fossil fuels; now a day's natural resources of petroleum products are rapidly decreased. Secondly it has lesser biodegradability characteristics [6]. Because of mineral oils are made upon hydrocarbon components with different molecular structure which is resists degradation behaviors of mineral oil. Due to such phenomenon several recharges are involves vegetable oils is used as a liquid dielectric in transformers. In this recharge work to examine pongamia pinnata oil (Karanja oil) is suitable for Distribution transformer or not?.

In this paper investigate the viscosity of pongamia pinnata oil as per ASTM D445 standards. Because vegetable oils are more viscous than the conventionally used insulation oil. This is used in reducing the fluid flow in the windings, cooling ducts and increases the operating temperature of the transformer. It has effectively reduced transformer life. So that investigation of any alternating liquid dielectrics viscosity is very essential. Also the water content of oil is deciding factor for quality of the insulating property of the oil. This analysis is performed by weight balance method. The efficiency of the oil is determined by its dielectric strength. Any new insulating oil requires at least $30 \mathrm{kV}$ dielectrics strength. So that breakdown strength test is conducted and compared with traditionally used mineral oil.

\section{Literature Review}

Santanu singe et al investigates viscosity of mineral oil as 
per ASTM D445 at $40^{\circ} \mathrm{C}$ comparing with High Oleic Natural Ester. Earlier than $1500 \mathrm{hrs}$ of operation the viscosity of natural and HONE oil is not stable. Up to 3500 hrs of operation the viscosity of high oleic natural ester and mineral oil almost no change. Because of the test is conducted under nitrogen atmosphere which limiting the influences of oxygen with ester oil. So that high oleic natural ester oil viscosity is highly suitable for hermetically sealed transformer applications [7].Stefan tenbohlen et al study effects of oxygen on viscosity of oil. Natural ester oil viscosity is strongly increased with influence of oxygen present in the air. The molecules of ester oils are divided into small element due to oxidation process where remaining molecules of ester oils involve a polymerization process; it strongly increases the viscosity of oil. So that to maintain ester filled transformer without contact with air. The mineral oil viscosity is affected by oxidation is very less as compared to ester oil [8].

M.H abderarazzaq et al measures various types of olive oil viscosity. The viscosity of new and old olive oils is 9.9and $11.6 \mathrm{cSt}$ respectively. Also the viscosity of naturally grown tree oil is $8.43 \mathrm{cSt}$ and irrigated Olive oil tree is $8.5 \mathrm{cSt}$ respectively. If temperature of oil increases it reduces the oil viscosity and increases the pressure inside the transformer. Hence viscosity of oil depends on temperature and pressure [9].

IL Hosier et al measures the viscosity of oil using physical reolabmcl at room temperature with and without catalyses added. The sunflower oil viscosity is significantly increased for all sampling periods where $\mathrm{DDb}$, environment temp and olive oil viscosity has no significance difference after aging. The corn oil and rapeseed oil viscosity is slightly increased when catalysis add in these oil. Here a copper wire isacted as a catalytic [10].

$\mathrm{R}$ karthic et al evaluates viscosity of mixing insulating liquids at $60^{\circ} \mathrm{C}$. The viscosity of ester oil, mineral oil and synthetic ester oils are $17.2 \mathrm{cSt}, 5.72 \mathrm{cSt}$ and $289.74 \mathrm{cSt}$ respectively. It infers that mineral oil have low viscosity than natural and synthetic ester oil. While synthetic ester oil viscosity is much higher than mineral oil and ester oil. The viscosity of $80 \%$ mineral oil mixing with $20 \%$ of synthetic ester oil is $16.92 \mathrm{cSt}$ while viscosity of $80 \%$ mineral oil is mixed with $20 \%$ of ester oil is $6.82 \mathrm{cSt}$. Hence the viscosity of synthetic ester, natural ester oil has to be significantly reduced by it mixing with mineral oil [11].

Yuvsnidan et al measuring the viscosity of mixed insulating fluid at $40^{\circ} \mathrm{C}$. The viscosity of mineral oil is $8.33 \mathrm{cSt}$ where viscosity of RBDPO is $37.95 \mathrm{cSt}$. From this measurement RBDPO have a much higher viscosity than mineral oil. If the concentration of RBDPO increases it decrease the overall viscosity[12].

A Raymon et al studies the effect of antioxidants mixing with vegetable oil. The viscosity of sunflower oil, Rice Bran oil, Soya bean oil and corn oils are 132,154,164, and $134 \mathrm{cSt}$ respectively this higher viscosity of oils is reduced by adding different quantities of antioxidants. After adding antioxidants Viscosity of Rice bran oil to reduced very little quantity only. In soya bean oil the viscosity of considerable decreased expect $5 \mathrm{~g}$ of butylated Hydroxyl and $5 \mathrm{~g}$ of acidic acids [13].

H. M. Wilhelm, L. Thalia et al measures the viscosity of Environtemp FR3 and Biotemp liquid at the temperature ranges of $20^{\circ} \mathrm{C}, 40^{\circ} \mathrm{Cand} 100^{\circ} \mathrm{C}$ as per ASTM D445 standard. In general viscosity of vegetable oil is 4 times higher than mineral oil. As the $20^{\circ} \mathrm{C}$ operating temperature viscosity of Environtemp FR3 oil is $77 \mathrm{cSt}$ which is lower than bitmap it has $82 \mathrm{cSt}$. Initially the vegetable oil viscosity is very high which is gradually decreased after $100^{\circ} \mathrm{C}$ of operating temperature [14].

Kailas M. Talkit et al. measures the viscosity of soyabean, sesame, coconut and sunflower oil using Redwood Viscometer No.1. Also author measures the viscosity of the soybean oil mix together with various proportions of sesame oil, coconut oil and sunflower oil. Up to $30^{\circ} \mathrm{C}$ of operation the viscosity of vegetable oils is very high. While beyond $80^{\circ} \mathrm{C}$ operating temperature the viscosity of vegetable oils significantly decreased. The mixing ratio of $10 \%$ soya bean oil with coconut oil has $18.18 \mathrm{CST}$ which is the minimum value as compared to all other combinations. The mixing of $90 \%$ soya bean with $10 \%$ coconut oil has a higher viscosity than all other combinations of oil mixing [15].S M Bashi et al measures the viscosity of RBDPO oil as per ASTM D88 and D445 Standard. Initially RBDPO oil viscosity is $500 \mathrm{cSt}$ when the operating temperature to reach a $40^{\circ} \mathrm{C}$ the viscosity of RBDPO oil is significantly reduced to $48 \mathrm{cSt}$. Ata $100^{\circ} \mathrm{C}$ operating temperature the viscosity of oil to reach $15^{\circ} \mathrm{C} \mathrm{St} \mathrm{[16].}$

H.M Wilhelm et al conducted an accelerated thermal aging test under oxygen flow rate 1 Lh-1 in a thermo-stabilized bath. The viscosity of Biovolt $\mathrm{A}$ and Refined vegetable oils are measured with and without adding antioxidants. At $40^{\circ} \mathrm{C}$ the viscosity of Biovolt $\mathrm{A}$ is $36.1 \times 10-6 \mathrm{~m} 2 / \mathrm{s}$ which is rapidly decreasing at $100^{\circ} \mathrm{C}$. At $40^{\circ} \mathrm{C}$ Sunflower oil have higher viscosities than refined soya oil, rice oil where at $100^{\circ} \mathrm{C}$ rice bran oil has a lower viscosity than others. Before adding antioxidants Refined soya oil, rice oil to reach a viscosity limit value after $2 \mathrm{hrs}$ while rice oil to reach a critical value after $10 \mathrm{hrs}$ of aging. After adding antioxidant refined soya oil, Sunflower reaches a limited value after $69 \mathrm{hrs}$. Where Refined rice oil to take $64 \mathrm{hrs}$, it infers that AD-4 antioxidants could be maintains the viscosity of vegetable oil within limits during the aging process [17].

From the literature review viscosity of vegetable oil is higher than that of mineral oil. At $40^{\circ} \mathrm{C}$ operating temperature the viscosity of all types of olive oils, High oleic natural ester oil and the blending combination of $80 \%$ of mineral oil with $20 \%$ ester oils are significantly decreased. At $100^{\circ} \mathrm{C}$ operating temperature EnvirotempFR3 and biotemp has the lower viscosity. From the above review it was found that even after the increase of operating temperature viscosity doesn't reduce below the level of viscosity of mineral oil. The various vegetable oil viscosity with different compositions are shown in appendix 1 . 


\section{Pongmia Pinnata}

Pungamia pinnata is a medium sized evergreen tree which grows in Indian subcontinent and south east Australia...etc It's a nitrogen fixing plan. A single tree can produce $9-90 \mathrm{~kg}$ seeds per year. The yield potential of tree is $900-9000 \mathrm{~kg} / \mathrm{ha}$. The seed oil content range between $30-40 \mathrm{wt} \%$ This tree is fast growing, drought resistant, moderately frost hardly and highly tolerant of sanity. Historically, this plant has been used in Indian and neighboring regions as a source of traditional medi-cines, animal fodder, green manure, timber, water-paint binder, pesticide, fish poison and fuel. Recently, Pongamia pinnata has been recognized as a viable source of oil for the biofuel industry. Since In 2003 the Himalayan Institute of Yoga Science and Philosophy was started campaign of education and public awareness to rural people related to extract Bio fuel from ponga oil. Due to this program at least 200 million pongama pinnata trees has been planted by 45,000 farmers. In power transformer Soya bean, Sun flower oil, Palm oil, Rice bran oil is also used as a liquid dielectric. These are the edible oil so research work focus on the non-edible oil as a liquid dielectrics $[18,19]$.

\section{Fatty Acids}

Vegetable oils have a triglyceride structure. It has different types of fatty acids which are saturated, monounsaturated and poly unsaturated fatty acids. These fatty acids are decides the physical and chemical property of the oil. A few vegetable oils are having higher saturated fatty acids; these vegetable oils are has higher viscosity while some vegetable oils are have higher un saturated fatty acids, it having lower viscosity. The pongamia pinnata $79.4 \%$ mono unsaturated fatty acids and $20.5 \%$ saturated fatty acids $[19,20]$.

\section{Experimental Analysis}

\subsection{Viscosity Measurement}

Viscosity of pongamia pinnata oil was measured using PLINT TE 62 Bench viscometer as per ASTM D445 standard. A $40 \mathrm{ml}$ of oil sample is poured into oil chamber of viscometer and press the start button. The viscosity of pungamia pinnata oil is measured against the operating temperature rise. The measurement has been made between room temperature $32^{\circ} \mathrm{C}$ to $90^{\circ} \mathrm{C}$.

\subsubsection{Result and Discussion}

At $32^{\circ} \mathrm{C}$ operating temperature the viscosity of pongamia oil is $75 \mathrm{cSt}$. The operating temperature of viscometer is increases this will decreases viscosity of pongamia pinnata oil as shown in table 1 and figure 1 . The viscosity of oil sample to be reached $17 \mathrm{cSt}$ at $90^{\circ} \mathrm{C}$.
Table 1. Viscosity of pongamia pinnata oil

\begin{tabular}{|c|c|}
\hline Temperature in ${ }^{\circ} \mathrm{C}$ & Viscosity in cSt \\
\hline 32 & 75 \\
\hline 34 & 65 \\
\hline 36 & 53 \\
\hline 38 & 45 \\
\hline 40 & 38 \\
\hline 50 & 33 \\
\hline 60 & 27 \\
\hline 70 & 23 \\
\hline 80 & 19 \\
\hline 90 & 17 \\
\hline
\end{tabular}

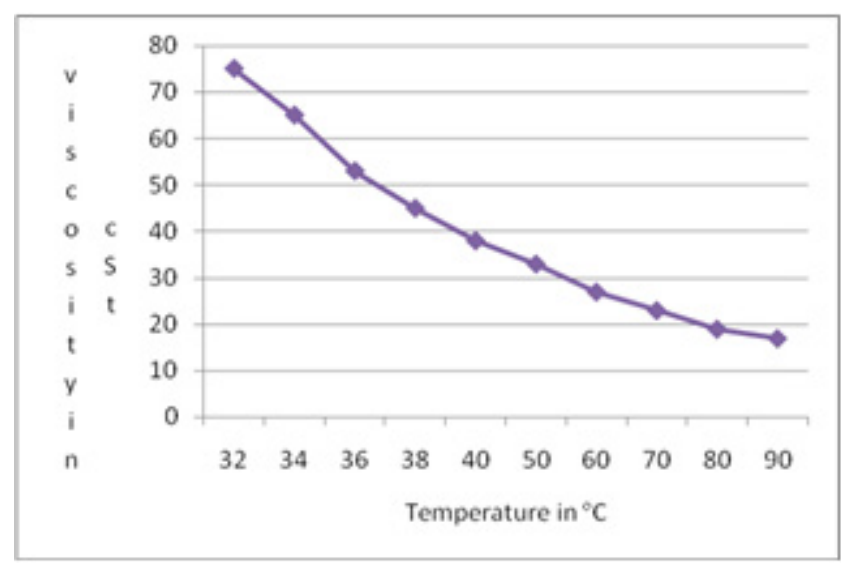

Figure 1. Viscosity (cSt) Vs Temperature in ${ }^{\circ} \mathrm{C}$

\subsection{Water Content of Pongamia Pinnata Oil}

The water content of insulating oil significantly affects physical and chemical property of the oil. Initially weight of pongamia pinnata oil sample is measured using fourth decimal accuracy weight balance meter. Later that pogamia pinnata oil sample is kept placed in Hot Air Oven at $100^{\circ} \mathrm{C}$ for 8 hours. After eight hours of oil sampling periods it allows cooling for 8 hours and then the oil mass is measured for the thermal and electrical degradation. The same oil is put into same aging process for 30 days. The mass of oil is tabulated and is converted to ppm value.

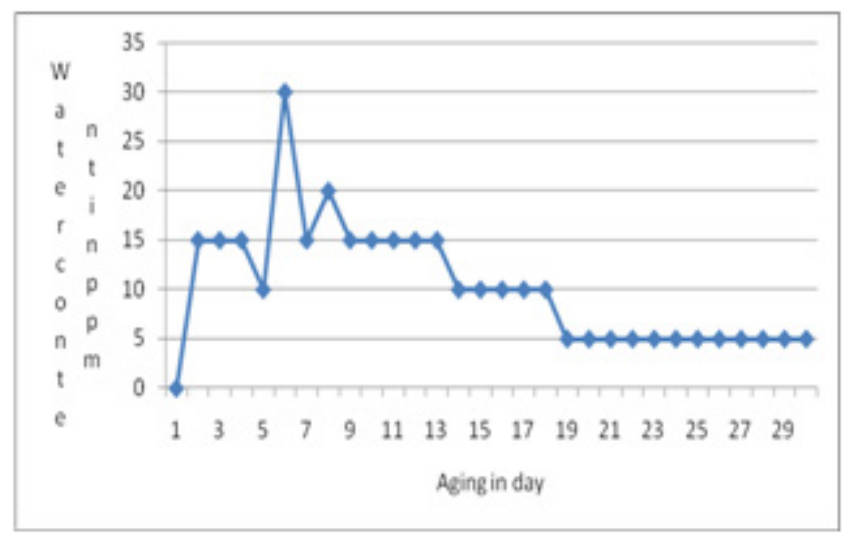

Figure 2. Aging vs Water content 
Pongamia Pinnata as Alternate Liquid Dielectrics in Distribution Transformer:

A Critical Study on the Property of Viscosity

Table 2. Water content analysis of pongami pinnat oil

\begin{tabular}{|c|c|c|c|c|c|c|c|}
\hline \multirow[b]{2}{*}{ Date } & \multirow{2}{*}{$\begin{array}{l}\text { weight of oil } \\
\text { before } \\
\text { testing in } \mathrm{mg} / \mathrm{kg}\end{array}$} & \multicolumn{3}{|c|}{ Testing duration } & \multirow{2}{*}{$\begin{array}{l}\text { weight of oil } \\
\text { after Testing } \\
\text { in } \mathrm{mg} / \mathrm{kg}\end{array}$} & \multirow[b]{2}{*}{$\% \mathrm{~W}=\left((\mathrm{w} 1-\mathrm{w} 2 / \mathrm{w} 2)^{*} 100\right)$} & \multirow{2}{*}{$\begin{array}{l}\text { Water content in } \\
\text { ppm }\end{array}$} \\
\hline & & $\begin{array}{c}\text { Starting } \\
\text { Time in hrs }\end{array}$ & $\begin{array}{c}\text { Ending } \\
\text { Time in } \mathrm{hrs}\end{array}$ & $\begin{array}{c}\text { Total Time } \\
\text { in hrs }\end{array}$ & & & \\
\hline $8 / 2 / 2014$ & 20.0004 & $9 \mathrm{am}$ & $5 \mathrm{pm}$ & 8 & 20.0001 & 0.00149999 & 15.00 \\
\hline $9 / 2 / 2014$ & 20.0001 & $9 \mathrm{am}$ & $5 \mathrm{pm}$ & 16 & 19.9998 & 0.00150002 & 15.00 \\
\hline $10 / 2 / 2014$ & 19.9998 & $9 \mathrm{am}$ & $5 \mathrm{pm}$ & 32 & 19.9995 & 0.00150004 & 15.00 \\
\hline $11 / 2 / 2013$ & 19.9995 & $9 \mathrm{am}$ & $5 \mathrm{pm}$ & 48 & 19.9993 & 0.00100004 & 10.00 \\
\hline $12 / 2 / 2014$ & 19.9993 & $9 \mathrm{am}$ & $5 \mathrm{pm}$ & 64 & 19.9987 & 0.0030002 & 30.00 \\
\hline $13 / 2 / 2043$ & 19.9987 & 9am & $5 \mathrm{pm}$ & 80 & 19.9986 & 0.00150012 & 15.00 \\
\hline $14 / 2 / 2014$ & 19.9986 & $9 \mathrm{am}$ & $5 \mathrm{pm}$ & 96 & 19.9982 & 0.00200018 & 20.00 \\
\hline $15 / 2 / 2014$ & 19.9982 & 9am & $5 \mathrm{pm}$ & 112 & 19.9979 & 0.00150016 & 15.00 \\
\hline $16 / 2 / 2013$ & 19.9979 & $9 \mathrm{am}$ & $5 \mathrm{pm}$ & 128 & 19.9976 & 0.00150018 & 15.00 \\
\hline $17 / 2 / 2014$ & 19.9976 & $9 \mathrm{am}$ & $5 \mathrm{pm}$ & 144 & 19.9973 & 0.0015002 & 15.00 \\
\hline $18 / 2 / 2014$ & 19.9973 & $9 \mathrm{am}$ & $5 \mathrm{pm}$ & 160 & 19.997 & 0.00150023 & 15.00 \\
\hline $19 / 2 / 2014$ & 19.997 & $9 \mathrm{am}$ & $5 \mathrm{pm}$ & 176 & 19.9967 & 0.00150025 & 15.00 \\
\hline $20 / 2 / 2014$ & 19.9967 & $9 \mathrm{am}$ & $5 \mathrm{pm}$ & 192 & 19.9965 & 0.00100018 & 10.00 \\
\hline $21 / 2 / 2014$ & 19.9965 & $9 \mathrm{am}$ & $5 \mathrm{pm}$ & 208 & 19.9962 & 0.00100019 & 10.00 \\
\hline $22 / 2 / 2014$ & 19.9962 & 9am & $5 \mathrm{pm}$ & 224 & 19.996 & 0.0010002 & 10.00 \\
\hline $23 / 2 / 2014$ & 19.996 & $9 \mathrm{am}$ & $5 \mathrm{pm}$ & 240 & 19.9957 & 0.00100021 & 10.00 \\
\hline $24 / 2 / 2014$ & 19.9957 & $9 \mathrm{am}$ & $5 \mathrm{pm}$ & 256 & 19.9955 & 0.00100023 & 10.00 \\
\hline $25 / 2 / 2014$ & 19.9955 & $9 \mathrm{am}$ & $5 \mathrm{pm}$ & 272 & 19.9954 & $5.00 \mathrm{E}-04$ & 5.00 \\
\hline $26 / 2 / 2014$ & 19.9954 & $9 \mathrm{am}$ & $5 \mathrm{pm}$ & 304 & 19.9953 & $5.00 \mathrm{E}-04$ & 5.00 \\
\hline $27 / 2 / 2014$ & 19.9954 & $9 \mathrm{am}$ & $5 \mathrm{pm}$ & 320 & 19.9953 & $5.00 \mathrm{E}-04$ & 5.00 \\
\hline $28 / 2 / 2014$ & 19.9954 & $9 \mathrm{am}$ & $5 \mathrm{pm}$ & 336 & 19.9953 & $5.00 \mathrm{E}-04$ & 5.00 \\
\hline $1 / 3 / 2014$ & 19.9954 & $9 \mathrm{am}$ & $5 \mathrm{pm}$ & 352 & 19.9953 & $5.00 \mathrm{E}-04$ & 5.00 \\
\hline $2 / 3 / 2014$ & 19.9954 & $9 \mathrm{am}$ & $5 \mathrm{pm}$ & 368 & 19.9953 & $5.00 \mathrm{E}-04$ & 5.00 \\
\hline $3 / 2 / 2014$ & 19.9954 & $9 \mathrm{am}$ & $5 \mathrm{pm}$ & 384 & 19.9953 & $5.00 \mathrm{E}-04$ & 5.00 \\
\hline $4 / 3 / 2014$ & 19.9954 & $9 \mathrm{am}$ & $5 \mathrm{pm}$ & 400 & 19.9953 & $5.00 \mathrm{E}-04$ & 5.00 \\
\hline $5 / 3 / 2014$ & 19.9954 & $9 \mathrm{am}$ & $5 \mathrm{pm}$ & 416 & 19.9953 & $5.00 \mathrm{E}-04$ & 5.00 \\
\hline $6 / 3 / 2014$ & 19.9954 & $9 \mathrm{am}$ & $5 \mathrm{pm}$ & 432 & 19.9953 & $5.00 \mathrm{E}-04$ & 5.00 \\
\hline 7/3/2014 & 19.9954 & $9 \mathrm{am}$ & $5 \mathrm{pm}$ & 448 & 19.9953 & $5.00 \mathrm{E}-04$ & 5.00 \\
\hline $8 / 3 / 2014$ & 19.9954 & 9am & $5 \mathrm{pm}$ & 464 & 19.9953 & $5.00 \mathrm{E}-04$ & 5.00 \\
\hline
\end{tabular}

\subsubsection{Result and discussion}

At the first sampling period the water content of pongamia pinnata oil is $14.99993 \mathrm{ppm}$. After 16 hours of sampling period the water content of oil is increased to $0.0022 \mathrm{ppm}$. After 64 hours of sampling time the moisture content of oil reaches $30.00195013 \mathrm{ppm}$ which is the maximum value. Up to $272 \mathrm{hrs}$ of sampling period the water content of pongamia pinnata oil is not stable. Above $272 \mathrm{hrs}$ of sampling periods the water content of pongamia pinnata oil has reached a stable value as shown in Table2,Fig 2 ,.

\subsection{Breakdown Strength of Pongamia Pinnata Oil}

The breakdown strength of Pongamia pinnata oil was measured as per IEC 60156 . The test was conducted by nutronics oil test kit, it having $0-80 \mathrm{kv}$ capacity. At first the test cup was washed by pongamia pinnata oil. After cleaning the oil is poured into test cup. The test cup has $2.5 \mathrm{~mm}$ gap spacing between two electrodes. After 5 minutes of pouring the oil, the supply mains are switched on. The applied voltage will be increasing at the rate of $2 \mathrm{kV} / \mathrm{s}$. The voltage will be rising until breakdown occurs inside the oil sample. Five consecutive measurements are made for accuracy.

Table 3. Breakdown strength

\begin{tabular}{|c|c|c|}
\hline SL.No & Pongamiapinnata oil BDV in kV & Mineral oil BDV in kV \\
\hline 1 & 77 & 67 \\
\hline 2 & 73 & 63 \\
\hline 3 & 59 & 52 \\
\hline 4 & 54 & 48 \\
\hline 5 & 51 & 42 \\
\hline
\end{tabular}




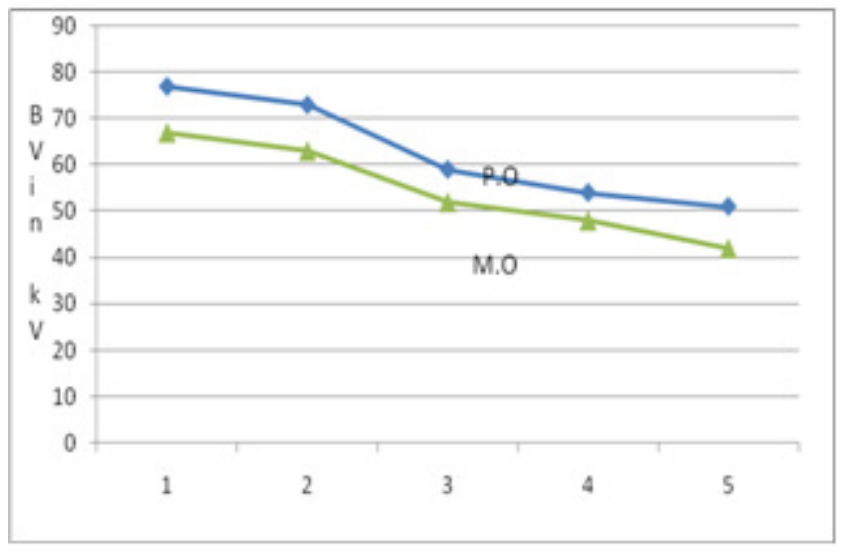

Figure 3. Comparison between Breakdown strength (BDV) of Pongamia pinnata oil(P.O) Vs Mineral oil(M.O)

\subsubsection{Result and Discussion:}

From the experimental results the average breakdown strength of pongamia pinnta oil is higher than the conventional used mineral oil. This satisfies the requirement for the breakdown strength of insulating liquid as per IEC standard. Also breakdown strength of pongamia pinnata oil is much higher than vegetable oils like sunflower oil, soya bean oil, coconut oil, corn oil and natural ester like BIOTEMP, ambient insulating fluid, Ambiant prime insulating fluid as shown Table 4.

\section{Conclusions}

From the experiment it is concluded that
[1]. $40^{\circ} \mathrm{C}$ operating temperature the viscosity of pongamia pinnata oil is low as compared to RBDPO, Soya bean oil, Sesame oil, Coconut oil and sunflower oil. Also it have higher amount of mono unsaturated fatty acids. Due to this pongamia oil has low viscosity.

[2]. Water content of pongamia pinnata oil has to be significantly reduced which is the satisfies the basic property of insulating oil

[3]. Average better breakdown strength is higher than the conventional used mineral oil.

In future, other physical and chemical properties are tested as per ASTM and IEC standard. If test results matches with liquid dielectrics properties it can replace the traditionaly used mineral oil in Distribution Transformer

Table 4. Breakdown strength comparison

\begin{tabular}{|c|c|c|}
\hline Name of oil & $\mathrm{BDV}$ in $\mathrm{kV}$ & Referred by \\
\hline Sunflower Oil & 34 & \multirow{4}{*}{13} \\
\hline Rice Bran Oil & 39 & \\
\hline Soya bean Oil & 27 & \\
\hline Corn Oil & 32 & \\
\hline coconut oil & 60 & 21 \\
\hline \multicolumn{3}{|c|}{ Ester oil } \\
\hline BIOTEMP & 45 & \\
\hline $\begin{array}{l}\text { Ambiant insulating } \\
\text { fluid }\end{array}$ & 55 & \\
\hline Ambiant prime insulating fluid & 51 & \\
\hline
\end{tabular}

\section{Appendix 1}

\begin{tabular}{|c|c|c|c|c|}
\hline Oil name & Testing standard & Operating Temperature & Viscosity & Refered by \\
\hline $\begin{array}{l}\text { High oleic natural oil } \\
\text { Mineral oil }\end{array}$ & ASTM D445 & At $40^{\circ} \mathrm{C}$ & $\begin{array}{l}40 \mathrm{cSt} \\
9.8 \mathrm{cSt}\end{array}$ & [7] \\
\hline HOSO & & $\begin{array}{l}\text { At } 40^{\circ} \mathrm{C} \\
\text { At }-20^{\circ} \mathrm{C} \\
\end{array}$ & $40 \mathrm{~mm}^{2} \mathrm{~s}^{-1}$ & \multirow{4}{*}{ [8] } \\
\hline FR3 & & $\begin{array}{l}\text { At } 40^{\circ} \mathrm{C} \\
\text { At }-20^{\circ} \mathrm{C} \\
\end{array}$ & $\begin{array}{l}33 \mathrm{~mm}^{2} \mathrm{~s}^{-1} \\
\text { App. } 500 \mathrm{~mm}^{2} \mathrm{~s}^{-1}\end{array}$ & \\
\hline Midel eN & & $\begin{array}{l}\text { At } 40^{\circ} \mathrm{C} \\
\text { At }-20^{\circ} \mathrm{C}\end{array}$ & $\begin{array}{c}37 \mathrm{~mm}^{2} \mathrm{~s}^{-1} \\
1485 \mathrm{~mm}^{2} \mathrm{~s}^{-1}\end{array}$ & \\
\hline Midel 7131 & & $\begin{array}{l}\text { At } 40{ }^{\circ} \mathrm{C} \\
\text { At }-20^{\circ} \mathrm{C}\end{array}$ & $\begin{array}{c}28 \mathrm{~mm}^{2} \mathrm{~s}^{-1} \\
1400 \mathrm{~mm}^{2} \mathrm{~s}^{-1}\end{array}$ & \\
\hline $\begin{array}{c}\text { Olive oil } \\
\text { Filtered new/ old }\end{array}$ & & \multirow{4}{*}{ At $40^{\circ} \mathrm{C}$} & 9.9/11.6 cSt & \multirow{4}{*}{ [9] } \\
\hline Olive oil Un filtered oil new/old & & & $9.9 / 11.6 \mathrm{cSt}$ & \\
\hline $\begin{array}{c}\text { Naturally grown } \\
\text { olive trees }\end{array}$ & & & $8.43 \mathrm{cSt}$ & \\
\hline $\begin{array}{c}\text { Irrigated } \\
\text { olive trees }\end{array}$ & & & $8.52 \mathrm{cSt}$ & \\
\hline Synthetic Ester oil & & At $60^{\circ} \mathrm{C}$ & $289.74 \mathrm{cSt}$ & \multirow{3}{*}{ [11] } \\
\hline Ester oil & & At $60^{\circ} \mathrm{C}$ & $17.2 \mathrm{cSt}$ & \\
\hline $80 \%$ mineral oil with $20 \%$ Ester oil & & At $60^{\circ} \mathrm{C}$ & $6.82 \mathrm{cSt}$ & \\
\hline
\end{tabular}


Pongamia Pinnata as Alternate Liquid Dielectrics in Distribution Transformer:

A Critical Study on the Property of Viscosity

\begin{tabular}{|c|c|c|c|c|}
\hline $100 \% \mathrm{MO}$ & \multirow{4}{*}{$\begin{array}{l}\text { ASTM D } 445 \text { and } \\
\text { ISO } 3104\end{array}$} & \multirow{4}{*}{ At $40^{\circ} \mathrm{C}$} & $8.33 \mathrm{cSt}$ & \multirow{4}{*}{ [12] } \\
\hline $100 \%$ RBDPO & & & $37.95 \mathrm{cSt}$ & \\
\hline $20 \% \mathrm{RBDPO} / 80 \% \mathrm{MO}$ & & & $11.86 \mathrm{cSt}$ & \\
\hline $90 \% \mathrm{RBDPO} / 10 \% \mathrm{MO}$ & & & $33.65 \mathrm{cSt}$ & \\
\hline $\begin{array}{l}\text { Sunflower } \\
\text { Oil }\end{array}$ & \multirow{5}{*}{ ASTM D 445} & \multirow{4}{*}{ At room temperature } & $132 \mathrm{cSt}$ & \multirow{11}{*}{ [13] } \\
\hline $\begin{array}{l}\text { Rice Bran } \\
\text { Oil }\end{array}$ & & & $154 \mathrm{cSt}$ & \\
\hline $\begin{array}{l}\text { Soya bean } \\
\text { Oil }\end{array}$ & & & $140 \mathrm{cSt}$ & \\
\hline $\begin{array}{c}\text { Corn } \\
\text { Oil }\end{array}$ & & & $134 \mathrm{cSt}$ & \\
\hline $\begin{array}{c}\text { 1gm of BHT with Sunflower } \\
\text { Oil }\end{array}$ & & At $30^{\circ} \mathrm{C}$ & $109 \mathrm{cSt}$ & \\
\hline $0.5 \mathrm{gm}$ of $\mathrm{BHT}+0.5 \mathrm{gm}$ of CA9 with sunflower oil & & \multirow{6}{*}{ At $30^{\circ} \mathrm{C}$} & $109 \mathrm{cSt}$ & \\
\hline $\begin{array}{c}\text { lgm of BHA with Rice Bran } \\
\text { Oil } \\
\end{array}$ & & & $143 \mathrm{cSt}$ & \\
\hline 5gm of BHA with Rice Brann oil & & & $143 \mathrm{cSt}$ & \\
\hline $\begin{array}{c}\text { gm of BHT with Soya bean } \\
\text { Oil }\end{array}$ & & & $103 \mathrm{cSt}$ & \\
\hline $\begin{array}{c}0.5 \mathrm{gm} \text { of } \mathrm{BHT}+0.5 \mathrm{gm} \text { of CA with Soyabean oil } \\
\alpha-\mathrm{T}+\mathrm{CA} \text { with soyabean oil }\end{array}$ & & & $103 \mathrm{cSt}$ & \\
\hline$\alpha-\mathrm{T}+\mathrm{CA}(0.5: 0.5)$ with corn oil & & & $105 \mathrm{cSt}$ & \\
\hline EnvirotempFR3 & \multirow{2}{*}{ ASTM D445 } & $\begin{array}{l}\text { At } 20^{\circ} \mathrm{C} \\
\text { At } 40^{\circ} \mathrm{C} \\
\text { At } 100^{\circ} \mathrm{C}\end{array}$ & $\begin{array}{c}77 \mathrm{cSt} \\
36 \mathrm{cSt} \\
8 \mathrm{cSt} \\
\end{array}$ & \multirow{2}{*}[14]{} \\
\hline Biotemp & & $\begin{array}{l}\text { At } 20^{\circ} \mathrm{C} \\
\text { At } 40^{\circ} \mathrm{C} \\
\text { At } 100^{\circ} \mathrm{C} \\
\end{array}$ & $\begin{array}{c}82 \mathrm{cSt} \\
40 \mathrm{cSt} \\
9 \mathrm{cSt} \\
\end{array}$ & \\
\hline Soybean oil & & $\begin{array}{l}\text { At } 30^{\circ} \mathrm{C} \\
\text { At } 40^{\circ} \mathrm{C} \\
\text { At } 50^{\circ} \mathrm{C} \\
\text { At } 60^{\circ} \mathrm{C} \\
\text { At } 70^{\circ} \mathrm{C} \\
\text { At } 80^{\circ} \mathrm{C} \\
\end{array}$ & $\begin{array}{l}78.83 \mathrm{cSt} \\
62.21 \mathrm{cSt} \\
48.20 \mathrm{cSt} \\
38.20 \mathrm{cSt} \\
32.34 \mathrm{cSt} \\
26.28 \mathrm{cSt} \\
\end{array}$ & \multirow{4}{*}{ [16] } \\
\hline Sesame oil & & $\begin{array}{l}\text { At } 30^{\circ} \mathrm{C} \\
\text { At } 40^{\circ} \mathrm{C} \\
\text { At } 50^{\circ} \mathrm{C} \\
\text { At } 60^{\circ} \mathrm{C} \\
\text { At } 70^{\circ} \mathrm{C} \\
\text { At } 80^{\circ} \mathrm{C}\end{array}$ & $\begin{array}{l}74.38 \mathrm{cSt} \\
57.48 \mathrm{cSt} \\
42.60 \mathrm{cSt} \\
33.54 \mathrm{cSt} \\
28.29 \mathrm{cSt} \\
25.30 \mathrm{cSt}\end{array}$ & \\
\hline Coconut oil & & $\begin{array}{l}\text { At } 30^{\circ} \mathrm{C} \\
\text { At } 40^{\circ} \mathrm{C} \\
\text { At } 50^{\circ} \mathrm{C} \\
\text { At } 60^{\circ} \mathrm{C} \\
\text { At } 70^{\circ} \mathrm{C} \\
\text { At } 80^{\circ} \mathrm{C}\end{array}$ & $\begin{array}{l}68.79 \mathrm{cSt} \\
62.41 \mathrm{cSt} \\
53.38 \mathrm{cSt} \\
46.10 \mathrm{cSt} \\
41.92 \mathrm{cSt} \\
28.30 \mathrm{cSt}\end{array}$ & \\
\hline Sunflower oil & & $\begin{array}{l}\text { At } 30^{\circ} \mathrm{C} \\
\text { At } 40^{\circ} \mathrm{C} \\
\text { At } 50^{\circ} \mathrm{C} \\
\text { At } 60^{\circ} \mathrm{C} \\
\text { At } 70^{\circ} \mathrm{C} \\
\text { At } 80^{\circ} \mathrm{C}\end{array}$ & $\begin{array}{l}76.98 \mathrm{cSt} \\
62.21 \mathrm{cSt} \\
48.20 \mathrm{cSt} \\
38.20 \mathrm{cSt} \\
32.34 \mathrm{cSt} \\
26.28 \mathrm{cSt}\end{array}$ & \\
\hline RBDPO & $\begin{array}{l}\text { ASTM D } 88 \text { and } \\
\text { D445 }\end{array}$ & $\begin{array}{c}\text { At } 0 \\
\text { At } 25^{\circ} \mathrm{C} \\
\text { At } 40^{\circ} \mathrm{C} \\
\text { At } 60^{\circ} \mathrm{C} \\
\text { At } 100^{\circ} \mathrm{C} \\
\end{array}$ & $\begin{array}{c}500 \mathrm{cSt} \\
300 \mathrm{cSt} \\
48 \mathrm{cSt} \\
30 \mathrm{cSt} \\
15 \mathrm{cSt}\end{array}$ & [17] \\
\hline
\end{tabular}




\section{REFERENCES}

[1] Vishal, Saurabh, Vikas and Prashant, "Transformer's History and its Insulating Oil", 5th National Conf., INDIACom, Computing For Nation Development, 2011.

[2] IEEE, Guide, "Loading Mineral-oil-immersed Transformers, Annex I: Transformer Insulation Life", IEEE Standard C57.91, 1995.

[3] IEEE 141-1993, IEEE Recommended Practice for Electric Power Distribution for Industrial Plants, Institute of Electrical and Electronic Engineers, 1999,

[4] J. Singh, Y. R. Sood, R. K. Jarial, and P. Verma, "Condition Monitoring of Power Transformers-Bibliography Survey", IEEE Electr. Insul. Mag., vol. 24, no. 3, pp 11-25, 2008.

[5] S. P. Balaji, I. P. M. Sheema, G. Krithika, and S. Usa, "Effect of Repeated Impulses on Transformer Insulation", IEEE Trans. Dielectr. Electr. Insul., vol. 18, no. 6, pp 2069-2073, 2011

[6] T.V. Oommen, Vegetable oils for liquid-filled transformers, IEEE Electrical Insulation Magazine 18 (1) . pp 6-11,vol.18, Jan.-Feb. 2002.

[7] Santanu Singha, Roberto Asano Jr., George Frimpong, C. Clair Claiborne and Don Cherry,"Comparative Aging Characteristics between a High Oleic Natural Ester Dielectric Liquid and Mineral Oil”, IEEE Transactions on Dielectrics and Electrical Insulation, vol. 21, No. 1;pp 149-158, February 2014.

[8] Stefan Tenbohlen, Maik Koch, " Aging Performance and Moisture Solubility of Vegetable Oils for Power Transformers", IEEE Trans. Power Del., vol. 25, no. 2,pp.825- 830, 2010.

[9] M. H. Abderrazzaq ,F. Hijaz, “ Impact of Multi-filtration Process on the Properties of Olive Oil as a Liquid Dielectric", IEEE Trans., on Diele., and Electrical Insulation ,vol. 19, no. 5, pp 1673- 1680, 2012.

[10] I. L. Hosier, A. Guushaa, E. W. Westenbrink, C. Rogers, A. S. Vaughan and S. G. Swingler "Aging of Biodegradable Oils and Assessment of their Suitability for High Voltage Applications" IEEE Transactions on Dielectrics and Electrical Insulation, vol. 18, no. 3, pp. 728- 738, June 2011.

[11] R. Karthik, T. Sree Renga Raja,S. S. Shunmugam \& T. Sudhakar, "Performance Evaluation of Ester Oil and Mixed Insulating Fluids", Journal of The Institution of Engineers (India): Series B, 93(3), pp173-178, September-November 2012.

[12] Yusnida M., Kiasatina Azmi, Mohd Azmier Ahmad, Zulkifli
Ahmadc, Mohamad Kamarol,"Breakdown Strength Characteristic of RBDPO and Mineral Oil Mixture as an Alternative Insulating Liquid for Transformer", Jurnal Teknologi (Sciences \& Engineering) 64:4,pp 69-72, 2013.

[13] A. Raymon, P. Samuel Pakianathan, M. P. E. Rajamani and R. Karthik, "Enhancing the Critical Characteristics of Natural Esters with Antioxidants for Power Transformer Applications", IEEE Transactions on Dielectrics and Electrical Insulation, vol. 20, no. 3, pp 899- 912, June 2013.

[14] H. M. Wilhelm, L. Tulio, R. Jasinski and G. Almeida, “Aging Markers for In-service Natural Ester-based Insulating Fluids", IEEE Transactions on Dielectrics and Electrical Insulation, vol. 18 , no. 3, pp 714-719, June 2011.

[15] Kailas M. Talkit, D.T.Mahajan, V.H.Masand, "Physicochemical Properties of Soybean Oil and Their Blends with Vegetable oils for the Evaluation of Lubrication Properties", Journal of Chemical, Biological and Physical Sciences, vol. 3, no. 1, pp. 490-497. November 2012- January 2013.

[16] S M Bashi, U. U Abdullahi, Robia Yunus and Amir Nordin, "USE OF NATURAL VEGETABLE OILS AS ALTERNATIVE DIELECTRIC TRANSFORMER COOLANTS", Journal - The Institution of Engineers, vol. 67, No. 2,pp 4-9, June 2006.

[17] H. M. Wilhelm, M. B. C. Stocco, L. Tulio W. Uhren and S.G. Batista, Jr., "Edible Natural Ester Oils as Potential Insulating Fluids", IEEE Transactions on Dielectrics and Electrical Insulation, vol. 20, no. 4,pp 1395-1401, August 2013.

[18] Mr.T.Mariprasath \& Mr.S.Ramkumar, Dr.V.Kirubakaran, "UTILIZATION OF PUNGAMIA PINNATA OIL A VIABLE SOURCE OF IC ENGINE AND DISTRIBUTION TRANSFORMER - A CRITICAL STUDY", International Journal of Advanced Technology \& Engineering Research (IJATER),pp 24-28,2014.

[19] Gaurav Dwivedi and M.P. Sharma, "Cold Flow Properties of Non Edible Oil in India International Journal of Applied Engineering Research,vol 8, no.16, pp. 1945-1952, 2013.

[20] Manju Bala , T. N. Nag, Sandeep Kumar, Manmohan Vyas, Arun Kumar, N. S. Bhogal, " Proximate Composition and Fatty Acid Profile of Pongamia pinnata, a Potential Biodiesel Crop”, Springer J Am Oil Chem Soc 88, pp 559-562, 2011.

[21] B. S. H. M. S. Y. Matharage, M. A. R. M. Fernando, M. A. A. P. Bandara, G. A. Jayantha, C. S. Kalpage "Performance of Coconut Oil as an Alternative Transformer Liquid Insulation" IEEE Transactions on Dielectrics and Electrical Insulation Vol. 20,no. ,pp. 887-898, 2013.

[22] Inmaculada Fernández, Alfredo Ortiz*, Fernando Delgado, Carlos Renedo, Severiano Pérez "Comparative evaluation of alternative fluids for power transformers" Elesivier Electric Power Systems Research 98, pp. 58-69, 2013 